\title{
EVALUATION AND CHARACTERIZATION OF GAKEM AND ABOUCHICHE CLAY SAMPLES IN BEKWARRA LGA OF CROSS RIVER STATE FOR USE AS REFRACTORY MATERIALS
}

\author{
F. A. Ovat ${ }^{1,}$, , D. E. Ewa ${ }^{2}$ and E. A. Egbe ${ }^{3}$ \\ 1 Dept. of Mechanical Engr., Cross River University of Technology, Calabar, Cross River State, Nigeria. \\ 2 Dept. of Civil Engineering, Cross River University of TeChnology, Calabar, Cross River State, Nigeria. \\ ${ }^{3}$ Cross River State Community and Social Development Agency, Calabar, Cross River State, Nigeria. \\ E-mail addresses:11 fraijoe@yahoo.com, 2desmondewa4sky@gmalil.com,3egbesonandy@yahoo.com
}

\begin{abstract}
The characterization of some clay as refractory materials for furnace lining has become relevant to find solutions to the cost involved in the purchase and importation of these refractory materials. This work investigated the refractory properties of clay samples for their suitability for use in the industries. Clay samples were collected from Gakem and Abouchiche areas and analysed for physical and chemical properties to determine the suitability of the clays as refractory materials. The results showed cold crushing strength $\left(21.46 \mathrm{MN} / \mathrm{m}^{2}\right)$, thermal shock resistance(27 cycles), bulk density(3.52g/ $\left.\mathrm{cm}^{3}\right)$, linear shrinkage(3.80\%), apparent porosity(28.84\%) and permeability(80\%) for Gakem; and cold cold crushing strength $\left(18.40 \mathrm{MN} / \mathrm{m}^{2}\right)$, thermal shock resistance(25 cycles), bulk density $\left(2.81 \mathrm{~g} / \mathrm{cm}^{3}\right)$, linear shrinkage(3.70\%), apparent porosity(25.86\%) and permeability(77\%) for Abouchiche respectively. The chemical compositions of these clay samples were also investigated. The results showed that the samples fall under Aluminosilicate type of clay because of their high values of Aluminium Oxide and Silicon Oxide. Tests showed that clay from these areas can be used to produce refractory materials that can withstand a furnace temperature of about $1600^{\circ} \mathrm{C}$.
\end{abstract}

Keywords: refractory, clay, Gachem, Abouchiche, Bekwara, materials

\section{INTRODUCTION}

Refractory materials are made from clay and are a set of materials that retain their strengths at high temperatures. They are non-metallic materials having those physical and chemical properties that make them applicable to structures or as components of systems that are exposed to high temperature applications. A material is refractory if it has a very high melting point in addition to its physical and chemical properties that makes it suitable for use in kilns, furnaces, reactors and other high temperature vessels [1]. According to them, refractory materials are materials capable of withstanding high temperatures, and that high quality refractory materials resist high temperature fluctuations between $1000^{\circ} \mathrm{C}$ and $1500^{\circ} \mathrm{C}$ and are also good thermal and electrical insulators.

It was observed by[2]that, the raw materials for the production of various types of refractory materials are kaolinite $\left(\mathrm{Al}_{2} \mathrm{Si}_{2} \mathrm{O}_{5}(\mathrm{OH})_{4}, \quad\right.$ Chromites $\left(\mathrm{FeCr}_{2} \mathrm{O}_{4}\right)$, Magnesite $\left(\mathrm{MgCO}_{3}\right)$ and various types of clays. He also noted that other additives such as sawdust, graphite and some binders are available locally.

The author of [3] studied the characteristics of Nigerian clays and established that Otukpo clay can withstand a furnace temperature of about $1710^{\circ} \mathrm{C}$ which compared favorably with imported refractories. [4] in his research on the characterization and evaluation of refractory properties of some clay deposits in Southwest Nigeria, reported that clays displayed reasonable refractory properties that compared favorably with standard values and recommended a blend of some clays for furnace lining. Meanwhile, [5] investigated the moulding properties of locally available clays for casting operations and observed that the Barkinladi and Alkaleri clay samples were suitable for construction of furnaces and their linings.

For chemical composition, refractories constitute either single or multi-component inorganic compounds with non-metallic elements [6]. They are classified as acid refractories, basic refractories and/or neutral refractories. The Acid refractories are a set of 
refractories used where slag and atmosphere are acidic. They cannot be used under basic conditions [2].

It was noted by [7] that, the main raw materials used for the production of these acid refractories are silica, $\mathrm{ZrO}_{2}$ and alumino-silicate; typical refractories are fire clay, quartz and silica. Basic refractories are produced from a composition of dead-burnt magnesite, dolomite, and chrome ore. Investigation by [8] on the applications of various refractories showed that magnesite, chrome combinations have good resistance to chemical action of basic slag, have good mechanical strength and volume stability at high temperatures. Chrome-magnesite refractories used for side walls of soaking pits, magnesite with varying amounts of carbon has excellent resistance to chemical attack by steel-making slag.

In their physical forms refractory materials are either bricks or monolithic. Shaped refractories are in the form of bricks of some standard dimensions [9]. Special shapes with required dimensions are hand-molded and are used for particular kilns and furnaces. Ramming refractories are in loose dry form with graded particle size and are often mixed with water for use. Investigation by [10] revealed that castable refractory materials contain binders such as aluminate cement which imparts hydraulic setting properties when mixed with water; the materials are installed by casting and are also known as refracting concretes. Research by [11] on the analysis and characterization of Nyikangbe clay deposit that, mortars are finely ground refractory materials which become plastic when mixed with water and are used to fill gaps created by a deformed shell, and to make walls gas-tight to forestall slag penetration.

The available literature is scanty on the investigation of Gakem and Abouchiche clays, it has become necessary to carry out such investigations to ascertain the suitability of clay deposit in these locations for their refractory properties.

\section{MATERIALS AND METHODS}

\subsection{Sample Collection}

Clay samples were collected from different locations of Gakem and Abouchiche of Bekwarra Local Government Area in the Northern Senatorial district of Cross River State. The samples were randomly collected from different points at a depth of $50 \mathrm{~cm}$ and about $25 \mathrm{~m}$ apart in a triangular manner.

\subsection{SAMPLE PREPARATION}

The samples of about $3 \mathrm{~kg}$ were collected and air-dried for five (5) days. Samples were then finely ground to achieve homogeneity of the particles sizes. The ground samples were sieved with a mesh of about1.13 $\mu \mathrm{m}$. The ground and sieved samples were mixed with some quantity of water to a pastry form. It was moulded (70x50x 50mm) into bricks and compacted with a hydraulic press according to ISO standards [17]. The different clay samples were subjected to both physical and chemical tests. The equipment used during the test included Son Holland-Telex 59388 Furnace, Oven, Navigator N3B110 Ohaus Electronic weighing machine, crusher, bell jar, dessicator, X-ray Spectrometer. These equipment can be found in the laboratory of Bao Yao Huan Jian Iron and Steel Company, Export Processing Zone (EPZ) Calabar, Cross River State-Nigeria.

\section{PHYSICAL ANALYSIS}

\subsection{Cold crushing Strength}

Test pieces measuring $75 \mathrm{~mm}$ by $50 \mathrm{~mm}$ by $50 \mathrm{~mm}$ were prepared and are-dried for 24 hours and were transferred to a furnace and heated for 6 hours and at a temperature of $1600^{\circ} \mathrm{C}$. After the heating process they were removed from the furnace and allowed to cool down to room temperature and each piece was in turn placed in a crusher. Load was applied axially and continually until the test piece failed. The procedure was repeated for other test pieces. The respective loads at which each test piece failed were recorded. The cold crushing strength (CCS) was calculated [1] using:

$\operatorname{ccs}=\frac{P}{A}$

In (1), A is the Area of specimen $\left(\mathrm{mm}^{2}\right)$ and P is the Load applied (N)

\subsection{Thermal Shock Resistance}

$75 \mathrm{~mm} \times 50 \mathrm{~mm} \times 50 \mathrm{~mm}$ test pieces were inserted in a furnace maintained at $1600^{\circ} \mathrm{C}$ for a period of about 10 minutes. The samples were removed and allowed to cool in a dessicator for 10 minutes and then returned back to the furnace (which is still at $1600^{\circ} \mathrm{C}$ ) for another 10 minutes. The process was repeated until the pieces were deformed when a small force is applied. The number of heating and cooling cycles for each of the specimen was recorded. The thermal shock resistance is the number of heating and cooling cycles needed to cause crack on the samples, the values obtained for the various locations were recorded in Table 1.

\subsection{Linear Shrinkage}

The samples were prepared and their original lengths of $75 \mathrm{~mm}$ recorded. They were dried in the air for 24 hours and then dried in an oven at $110^{\circ} \mathrm{C}$ for 24 hours and were then transferred to a furnace maintained at $1600^{\circ} \mathrm{C}$ and heated for a period of 6 hours. They were then brought out by means of a pair of tongs and allowed to cool in a dessicator. The samples were measured after heating and their linear shrinkage values determined [2] using:

Vol. 36, No. 3, July 2017 
Linear Shrinkage $=\frac{\mathrm{L}_{\mathrm{D}}-\mathrm{L}_{\mathrm{F}}}{\mathrm{L}_{\mathrm{D}}} \times 100$

Here, $\mathrm{L}_{\mathrm{D}}$ is the dried or original length $=75 \mathrm{~mm}$, and $\mathrm{L}_{\mathrm{F}}$ is the Fired length

\subsection{Bulk Density}

Bulk density was determined by air-drying for 24 hours, thereafter the test pieces were then put in an oven and dried at a temperature of $110^{\circ} \mathrm{C}$ for 6 hours. They were allowed to cool and weighed by means of weighing balance and their dried weights (D) recorded in turn. They were thereafter transferred to a beaker and heated for 40 minutes and cooled and the soaked weight was recorded. Water was put in another beaker and each of the test pieces in turn suspended in the water so that their suspended weights were recorded. The equation for calculating bulk density is given by [1] as:

Bulk Density $=\frac{D \rho W}{W-S}$

In (3), $D$ is the Dried weight, $\rho w$ is the Density of water, $W$ is the soaked weight and $S$ is the suspended weight.

\subsection{Apparent Porosity}

Test pieces from the different locations were prepared and allowed to dry in air for about 24 hours before transferring them to the oven and drying for another 24 hours at $110^{\circ} \mathrm{C}$. They were thereafter transferred to a furnace and fired to a temperature of $1600^{\circ} \mathrm{C}$, the samples were removed by pair of tongs and allowed to cool in open air before weighing them in a dessicator and noted the dry weight $\left(D_{w}\right)$. Bubbles were observed as the pores in the samples were filled with water. The bubbles were made to escape through periodic agitation and after about 40 minutes, and then weighed in the dessicator so that their soaked weights $\left(\mathrm{S}_{\mathrm{w}}\right)$ were noted. Also, by means of beaker placed on a balance, the specimens were weighed suspended in water and the suspended weight (W) was taken. The apparent porosity for each location was determined from [2] as:

Apparent porosity $=\frac{S_{W}-D_{W}}{S_{W}-W} \times 100$

Here $S_{W}$ is the Soaked weight, $D_{W}$ is the dried weight, and $W$ is the suspended weight

\subsection{Permeability}

Different samples were prepared and air-dried for 24 hours and thereafter oven dried at $120^{\circ} \mathrm{C}$ for 12 hours. Two thousand cubic centimeter of air held in a bell jar was forced to pass through the specimen. At this time, air entering the specimen was equal to that leaving the specimen. The pressure difference was read by a manometer, and noted. The time taken for the $2000 \mathrm{~cm}^{3}$ of air to pass through the specimen was recorded. The respective permeabilities were calculated from [2] using:
Permeability number, $\mathrm{P}_{\mathrm{n}}=\frac{V h}{A P t}$

In (5), $P_{n}$ is the permeability number, $V$ is the Volume of air, $\mathrm{cm}^{3}, h$ is the height of specimen, $\mathrm{cm} A$ is the Cross sectional area of specimen, $\mathrm{cm}^{2}, P$ is the pressure of air in $\mathrm{cm}$ of water, $\mathrm{N} / \mathrm{cm}^{2}$ and $t$ is the time, minutes

Modulus of Rupture (MOR): Different test pieces of clay bar, $75 \mathrm{~mm} \times 50 \times 50 \mathrm{~mm}$ dimension were prepared, the dry samples were moistened and mixed to a workable state .The wedged samples was cast in wooden mold, coated with thin film of machine engine oil. The bars were (temperature marked) then charged into an electric furnace separately along with American standard pyrometric cones of refractoriness $1600^{\circ} \mathrm{C}$ and fired for approximately ten hours, removed from the furnace and allowed to cool. Each batch of bars were broken at the center bending on a Denison strength testing machine at 7.0 span and MOR was calculated from the expression [13] as follows:

MOR $=\frac{3 P L}{2 b h}$

Here $\mathrm{P}$ is the Breaking Load in kgf, L is the Distance between support, $b$ is the Breath and $h$ is the Height

\subsection{Modulus of plasticity (MOP)}

The molded clay was deformed by dropping onto it from a fixed height of a flat-headed plunger of known weight. The distance traveled was read from the graduated scale. The modulus of plasticity (MOP) for the clay sample was obtained from [14] as:

MOP $=\frac{\text { Original Height }}{\text { Deformed Height }}$

Also, the percentage making moisture for the clay samples were obtained from [14 as:

$\%$ Making Moisture $=\frac{\text { Wet Weight }- \text { Dry Weight }}{\text { Net Weight }}$

\section{CHEMICAL ANALYSIS}

The Chemical Analysis of the clay samples was done using X-Ray Fluorescence Spectrometer (XRFS). The technique was used to determine the concentrations of elements present in the various samples. The samples were ground and sieved to produce $75 \mu \mathrm{m}$ particle sizes. Thereafter, 2grams of the sieved samples were mixed with 5 grams of lithium tetra borate binder $\left(\mathrm{Li}_{2} \mathrm{~B}_{4} \mathrm{O}_{7}\right)$ anhydrous solution that acts as a bonding agent. It was then pressed to a pellet in a mould and then dried in oven at $120^{\circ} \mathrm{C}$ for 20 minutes to remove the absorbed moisture and kept in a desicator. The spectrometer was turned on and allowed to warm up to stabilize the optics and x-ray tube. The samples were placed in the machine and the elemental concentrations present in the samples 
were displayed on the monitor. The result of the analysis is as given in Table 2 .

\section{RESULTS AND DISCUSSION}

The results obtained from the various tests carried out in chapter three are presented in Table 1 and Table 2. The tests revealed that, while most of the results agree with previous research, others are at variance.

Table 1: Physical Properties of the tested clays from Cross River State

\begin{tabular}{lll}
\hline Properties & Gakem & Abouchiche \\
\hline Cold Crushing Strength (MN $/ \mathrm{m}^{2}$ & 21.46 & 18.40 \\
$\begin{array}{l}\text { Thermal shock Resistance } \\
\text { (Cycles) }\end{array}$ & 27 & 25 \\
Linear Shrinkage (\%) & 3.80 & 3.70 \\
Bulk Density (g/ cm ${ }^{3}$ & 3.52 & 2.81 \\
Apparent Porosity (\%) & 28.84 & 25.86 \\
Permeability (\%) & 80 & 77 \\
Modulus of Rupture (Kgf/ $\left.\mathrm{cm}^{2}\right)$ & 47.21 & 45.0 \\
Modulus of plasticity $\left(\mathrm{Kgf} / \mathrm{cm}^{3}\right)$ & 30.5 & 3.60 \\
\hline
\end{tabular}

Table 2: Chemical Composition of clay samples at $1600^{\circ} \mathrm{C}$

\begin{tabular}{ccc}
\hline Elements/compound & Gakem & Abuochiche \\
\hline $\mathrm{Al}_{2} \mathrm{SO}_{3}$ & 29.09 & 30.65 \\
$\mathrm{SiO}_{2}$ & 56.44 & 58.09 \\
$\mathrm{MgO}$ & 0.14 & 0.11 \\
$\mathrm{CaO}$ & 0.12 & 0.19 \\
$\mathrm{Fe}_{2} \mathrm{O}_{3}$ & 2.56 & 2.9 \\
$\mathrm{~K}_{2} \mathrm{O}$ & 2.19 & 0.98 \\
$\mathrm{Cl}$ & 0.026 & 0.018 \\
$\mathrm{Co}$ & 0.035 & 0.017 \\
$\mathrm{MnO}$ & 0.00 & 0.047 \\
$\mathrm{Cr}_{2} \mathrm{O}_{3}$ & 0.06 & 0.048 \\
$\mathrm{Na}_{2} \mathrm{O}$ & 1.249 & 0.373 \\
$\mathrm{Ni}$ & 0.045 & 0.079 \\
$\mathrm{Cu}$ & 0.044 & 0.027 \\
$\mathrm{P}_{2} \mathrm{O}_{5}$ & 0.053 & 0.049 \\
$\mathrm{SO}_{3}$ & 0.025 & 0.029 \\
$\mathrm{Sr}$ & 0.00 & 0.020 \\
$\mathrm{TiO}_{2}$ & 0.897 & 1.513 \\
$\mathrm{Zr}$ & 0.03 & 0.106 \\
\hline
\end{tabular}

\section{DISCUSSION}

\section{1 Linear shrinkage}

The linear shrinkage is an indicator of the firing efficiency of the clay samples. However, [5] pointed out that lower values were more desirable as this means the clay is less susceptible to volume change. That means the values obtained from Gakem and Abouchiche having shrinkages of $3.80 \%, 3.70 \%$ respectively will make for very good refractory materials. These values compete favourably with those obtained by [16] in his investigation.

\subsection{Bulk density}

The bulk density is a measure of the weight of a given volume of refractory and is often considered in conjunction with porosity. Gakem had the highest values of bulk density of $3.52 \mathrm{~g} / \mathrm{cm}^{3}$ compared to that of Abouchiche. However, these values showed that these clays are good when compared with values obtained from Gur and Yamarkumi clays (2.06-2.11 g/ $\left.\mathrm{cm}^{3}\right)$, Plateau and Bauchi clays $\left(1.94-2.04 \mathrm{~g} / \mathrm{cm}^{3}\right)$, as respectively reported by [5] and [15].

\subsection{Apparent Porosity}

The values for Gakem and Abouchiche fall within the internationally accepted range of $20-30 \%$ as was noted by [2].

\subsection{Thermal Shock Resistance}

The thermal shock resistance determines the ability of the material to withstand repeated heating and cooling cycles. Gakem withstood thermal value of 27 cycles which makes them suitable for long term refractory use as these measure their longevity which in turn could result to cost saving due to minimal replacement. Also Abouchiche, having 25cycles each fall within the accepted range. These values are within the range recommended by [15] for refractory materials

\subsection{Cold Crushing Strength}

This is a measure of the ability of the clay to withstand abrasion and loading. Values that are recommended are above $18 \mathrm{MN} / \mathrm{m}^{2}$ and the areas investigated, Gakem and Abouchiche, have all met the standard, in other regions, [1] reported $26.5 \mathrm{MN} / \mathrm{m}^{2}$ for Nsu clay, while [4], reported $18.065 \mathrm{MN} / \mathrm{m}^{2}$ and $16.620 \mathrm{MN} / \mathrm{m}^{2}$ for Nyikangbe and Beji clays. However, the values of cold crushing strength for Gakem and Abouchiche are $21.46 \mathrm{MN} / \mathrm{m}^{2}$ and $18.46 \mathrm{MN} / \mathrm{m}^{2}$ respectively. This implies that, the clay samples from these locations have acceptable cold crushing strength values.

\subsection{Permeability}

Permeability is the measure of the ability of the clays to prevent gases and liquids from penetrating the walls. The permeability numbers of all the samples fall within the standard range of $25-90 \%$ as given by [2] Refractories under the influence of liquids and gases should be impervious, as this will help to eliminate leakage of gases 
and penetration of liquids through the walls of the furnace [12].

\subsection{Chemical Composition}

The results obtained from the chemical analysis of clay samples from Gakem and Abouchiche shows that for Gakem alumina (29.09\%), silica (56.44\%) and Abouchiche samples contained alumina (30.65\%), silica (58.09\%). Other elements such as $\mathrm{MgO}, \mathrm{CaO}, \mathrm{Fe}_{2} \mathrm{O}_{3}$ and $\mathrm{K}_{2} \mathrm{O}$ for Gakem were $0.14 \% 0.12 \%, 2.56 \%$ and $2.09 \%$ respectively. Those for Abouchiche were 0.11\%, 0.19\%, $2.90 \%$ and $0.9 \%$ for $\mathrm{MgO}, \mathrm{CaO}, \mathrm{Fe}_{2} \mathrm{O}_{3}$ and $\mathrm{K}_{2} \mathrm{O}$ respectively. The degree of refractoriness increases with alumina content, while the presence of alkali and their earth metals oxides is in low concentration lowers its fusion temperature and also accounts for relatively high refractoriness [13]. The clay samples from Gakem and Abouchiche satisfies the above conditions by virture of their chemical compositions interms of elemental values. The presence of $\mathrm{Fe}_{2} \mathrm{O}_{3}$ contributed to the reddish colour of both clay samples from grey. This colour changed after the firing process when carbonaceous materials and the iron began to oxidize [14].The proportion of elemental composition of iron in clays determines the thermal conductivity potential of such materials any fire clays to be used in refractories should have at least 30\% Alumina and less than $1.8 \%$ Iron (III) Oxide. However, with the use of the XRFS equipment for the chemical analysis, other compounds and elements were found to exist in the samples tested but in very low percentages as shown in Table 2.

\section{CONCLUSION}

Despite vast amounts of clay deposits in the country, we are yet to set up any refractory industry for the production of locally made refractories products. Nigeria depends till now, on the importation of these refractories for use in its manufacturing industries and refractory products. The uncertainty faced by the manufacturing industries and the decrease in economic growth, selfimposed on the nation's economy has necessitated the need to source for local raw materials. This study has shown that Gakem and Abouchiche clay samples have good refractory properties, hence they can be used as refractory materials. In addition to refractory materials these clays proved their applications to other areas such as ceramics, high melting clays, tiles, colored vaze and even porcelain.

\section{REFERENCES}

[1] Ameh, E. M. and Obasi, N. W. "Effect of rice husk on insulating bricks produced with Nafuta and Nsu clays",
Global Journal of Engineering and Technology, 2(4), pp.661-668, 2012.

[2] Omowumi O. S.“Characterization of some Nigerian Clays as Refractory Material for Furnace Lining”, Nig. Found. Eng. Manag.2(3), pp.1-4, 2001.

[3] Nnuka, E. E. and Enejor, C. "Characterisation of Nahuta clay for industrial and commercial applications", Nigerian journal of Engineering and materials.2(3), 912, 2010.

[4] Amuda, N. P. "Characterization and evaluation of refractory properties of some clay deposits in south west Nigeria". Engineering Journal, 4(3), pp. 33-39, 2005.

[5] Abolarin, M. S., Olugboji, O. A. and Ugwuoke, I. C. "Determination of Moulding properties of Locally Available Clays for Casting Operations", Assumption University Journal of Technology, 9(4), pp.238-242, 2006.

[6] Onyemaobi, 0. 0."Mineral Resources Exploitation, Processing and Utilization", A Sine Qua Non for Nigeria's Metallurgical Industrial Development Inaugural Lecture Series 5 of FUTO- Owerri, July, 10 (3), pp159-162, 2002.

[7] Irabor, P. S. "Physical and Chemical Investigation on some Nigerian kaoline clays for use in the ceramic and allied industries," Nigerian J. Eng. Res. Dev..1(1), pp54$59,2002$.

[8] Gupta, 0. P. Elements of Fuels, Furnaces and Refractories, New Delhi Khanna Publishers, 2008.

[9] Olokode O. S, Aiyedun P. O, Kuye S. I, Anyanwu, B. U, Owoeye F. T, Adekoya T. A, Nwonah J. N. "Optimization of the quantity of wood ash addition on kaolinite clay performance in porcelain stoneware tiles". Pacific. J. Sci. Technol. 14(1), pp. 48-56, 2013.

[10] Johari, I., SaidS., Jaya, R. P. and Bakar, B. H. A.“Chemical and Physical properties of fired clay brick at different type of Rice Husk ash", International conference on environment science and Engineering, Singapore. August8-11, pp.8-13, 2011.

[11]Onyeji, L. I. "Analysis and Characterization of Onyikangbe clay deposits, Chachanga L. G. A., Niger State", JMME,3(2 ), pp. 55-62, 2002

[12]Waing, W. K., Shwe, W. H. and Kay, T. L. "Study on the production of chromite refractory brick from local chromite ore", World Academy of Science, Engineering and Technology, 4 (2), pp. 569-574, 2008.

[13] Thring M. W. The science of flames and furnaces, London: Chapman and Hall Ltd, 1962.

[14]Rice, P. M. Pottery Analysis, Chicago: Chicago Press, 1987.

[15] Murray, H. H. Clay industrial minerals and rocks, New York: American institute of mining metal and petroleum engineering press, 1960.

[16] Omotoyinbo J. A and Oluwole 0. O. "Working properties of some selected refractory clay deposits in south western Nigeria", J. Miner. Mater. Characterize at .Eng. 11 (1), pp.1050-1054, 2008.

[17] https://www.iso.org $>$ iso $>$ pub 100288. Accessed on January 12, 2017. 